\title{
Divine Love as a Base for Transformation: A Case of Nyai Masriyah Amva from Cirebon, West Java
}

\author{
Sulaiman \\ Universitas Islam Negeri Walisongo Semarang, Jl. Walisongo 3-5 Semarang, \\ Central Java, Indonesia \\ \{sulaiman@walisongo.ac.id\}
}

\begin{abstract}
This paper examines the thoughts of Masriyah Amva, the leader of the Kebon Jambu Al-Islamy pesantren in Cirebon, West Java. The selftranscendence that occurred in Masriyah Amva was a very deep process of soul struggle so that she made God the Center. God became the object of Divine Love which aroused great fighting power for Masriyah Amva. With this Divine Love, she has an actual spirit and gives meaning and value to struggle as part of self-actualization towards perfection. The implication of Divine Love being the basis for transformative values encourages her to become a frame of mind and action, so that her thoughts and actions bring benefits to larger interests, no longer related to her personal interests. The implication of the former is Masriyah Amva's courage to give new colors to Islamic discourses that have been "taboo" in the pesantren world. She dared to discuss Divine Love as the basis of her struggle for social change. The most concern is women empowerment. She wants women to be independent and no longer have dreams of leaning on men. Because, the independence of women is also the independence of the future of their children who will create the nation's next generation..
\end{abstract}

Keywords: Divine Lov; God; Pesantren; Transformation; Masriyah Amva

\section{Introduction}

The Divine Love occupies the most important position for Islamic mystics (Sufis). In their doctrine, to know ourselves, we must know God. To know God, we must learn the mysteries of ourselves. And love is the key to unlocking this mystery. The mystery of existence is explained through divine love in the utterances of the first person associated with the Prophet Muhammad. In the Hadith Qudsi it is stated that God reveals as a hidden treasure: "I am a treasure, and I like being known closely. So, I created the heavens and the earth so that you might know Me." Here love is spoken of not as an emotion, not as a feeling or sentiment (even though it fills each other up and overflows). On the contrary, love is seen as releasing God into this plane of existence. It is through love that God creates the cosmos, through love we are sustained, and by joining the current of cosmic love we are brought back Home (Primordial Covenant).[1, p. xxiii] For this reason, mystics have agreed that Divine Love is the ultimate goal of all stations (maqāmāt) and the highest peak of all levels. There is no station after love 
unless it is a fruit and its consequences such as longing (syūq), liking (ins), pleasure (riḍā ') and so on.[2, p. 321] There is no station before love (mahabbah) unless it is a preamble such as repentance, patience, asceticism, and others. According to William C. Chittick, God is the the source of all love, just as He is the source of all other things. But what does mean "God is Love"? In fact, in the Koran we find many verses which state that love is a attribute of God. The Koran says that Allah loves something. By referring to this verse: then Allah will bring a people, whom He loves and who love Him, humble towards the believers, mighty against the disbelievers, striving hard in Allah's way and not fearing the censure of any censurer (Q. 5: 54).[3, pp. 195-196]

The phrase "God is Love" has been guided by the Lovers of God as He who is full of love and this condition has colored servant with God. God created with love, so that all His creatures carry the seeds of divine love within him. Through the reason given by God, man builds a relationship with God based on this love. However, in the doctrines formulated by the formal religious authorities, the servant's relationship with Allah is still dominated by the lure of the pleasures of heaven or the threat of hell's torment. This condition is often a source of tension between Sufis and Islamic jurists. In fact, in the Koran, it is clear, God explicitly affirms that His compassion includes all things (Q. 7: 156).[4, p. 161] Freed from an old impasse, Divine Lovers will generate tireless fighting power to pursue the blessing of their beloved. The lover's blessing is a prerequisite for meeting the lover. How will a meeting occur without your blessing and approval? There is no love that does not long for meeting. In this connection the Prophet Muhammad SAW said, "Whoever likes to meet Allah, Allah will bless meeting him." Like to meet means expecting to meet as often as possible.[4, p. 194] For the sake of obtaining the blessing and meeting with God is what has prompted Lovers to prove it in real action during this life. Because of that, this lover has taken various transformative actions.

Associated with these transformative actions, a divine lover can be seen from the figure of an Indonesian female ulama, , Mrs. Hj. Masriyah Amva. The theme of love echoed by $\mathrm{Hj}$. Masriyah Amva, through two of her works, Saat Aku Gila Cinta (When I'm Crazy in Love)[5] and Tafakur Cinta (Meditation of Love)[6] provide valuable information about the dynamics of Islamic discourse in the world of traditional Islamic boarding schools (pesantren) in Indonesia. This discourse is increasingly interesting to study because it was born from a female figure. Of course the expressions of love expressed by Amva will be very feminine and at the same time represent what Annemarie Schimmel calls from the emotion of virahini (a woman whose longing is not satisfied) for God until she finally reaches the wasli (one who has arrived or has been "united") with God.[7] On the other hand, these works also prove that pesantren is not only a religious education system, but also a literary agent.[8]

To explore Masriyah Amva's figure, this research uses self-transcendence theory and role theory. Self-transcendence refers to the highest, most holistic, and most inclusive level with regard to human consciousness, how to behave, as well as efforts to find the relationships that exist between oneself and the closest people, self with fellow humans, self with other living beings, self with the environment, and also self with the universe.[9] While from the perspective of role theory, roles are explained as a set of prescriptions about the actions Amva should take as a female ulama and leader of the Kebon Jambu Al-Islamy Pesantren in Cirebon, West Java. This position is determined by various variables such as social norms, demands and regulations, the roles that other people play in similar positions, and Amva's particular capacity and personality. The role is then understood as the result of social perception, Amva's behavior towards action behavior, and the variations displayed by other 
individuals in playing similar roles that are generated in the framework of work created by the factors previously mentioned.[10], [11]

\section{Main Reasons to Transform}

Love for God generates a desire and a yearning to return to Him.[12, p. 78] This love will encourage the lover to commit three important things, namely repaying God's love, pursuing His blessing, and giving value and meaning to human life. In connection with these three things, we will explore Masriyah Amva's ideas in practicing and realizing them throughout his life.

\subsection{Repay God'Love: God is the Center}

Masriyah Amva proved her love for God by making God the Center. It should note that Masriyah Amva's decision made God as the Center or the Foundation after going through a journey that was full of life's twists and turns. She realized that it was impossible to rely on other people, including her husband, because their abilities were limited and their level of patience was also limited.[13, p. 102] For her, Allah is the source of his strength in facing his weaknesses.[14, p. 110] Masriyah Amva has a prayer formula which she conveys in verses of poetry.

O Allah...

If You didn't help me in facing my problem, you would be a very loser in this world and my hereafter.

If You did not love and love me, who would love and care for me in this situation?

Then where will I run for help?

If You don't give me enough sustenance, then where will I ask?

You are the Most Sufficient and

Most Generous who will suffice me

So that I don't ask for help from other than You.[13, pp. 103-104]

As a consequence of God as her center or foundation, Masriyah Amva fully believes that $\mathrm{He}$ is an eternal leaning place, which never fades and leaves. In addition, by relying on Him, God will not demand anything from her and will not impose millions of new burdens on her shoulders. Instead, she got sprinkles of His gifts such as calm and strength, hope and reality.[15, p. 67]

Awareness of the need for God and surrender to Him have resulted in the strength and independence that formed Masriyah Amva's strong and independent figure. Therefore, she dared to emphasize her attitude, "I want to be independent; I want to be immortal." This independence and immortality can only be obtained by relying on the Source of Independence and the Almighty. His independent existence will only occur with His existence, and his immortality will only occur by His will. In this condition, according to Masriyah Amva, all these beauties will only happen if she relies on Him, not on the noble man who will be her companion. Because the man is mortal, his greatness is mortal, his glory is mortal. Based on this fact, the only person worthy of love is He the Eternal. Indeed, only with Himself will we get social, economic and a million other independence.[15, p. 72] Husein Muhammad described God for Masriyah Amva as the central point of all. As the Central Point, God is the 
place to complete everything that she experiences in her entire life. In Husein Muhammad's statement:

"Every time we met and talked, she often says that complaints against creatures are often disappointing. They are unable to answer their needs which keep on flowing like very fast water, they are busy with their needs which also continue to demand them, so if I always come knocking on their door, then what will happen? When all my troubles find no door or window, I just lean on God and love Him all and fully.” [16, pp. xvi-xvii]

According to Masriyah Amva's confession, she prefers to always come to Him with request after request, and always greet Him with praise. In this way, she really feels the benefit of the activity of approaching Him so that she always gets His help through the coincidences that He creates and at the same time she gets a sense of calm and serenity. Therefore, without the slightest doubt she declared that approaching God was a necessity. Even though everyone knows that she is a heap of weaknesses and flaws. It is a heap of negativity and ignorance.[16]

In another part, Masriyah Amva also underlined that when a person does not have anything, property, honor, appreciation, then at that time he will be able to see the highest point, namely Allah. In a very pinched and squeezed state, which no human can help and look at, it makes a person only feel the existence of Allah in her. While other creatures she considered useless and meaningless.[17, pp. 99-100] This conditions will give rise to a very special spiritual experience in a person so that she is no longer attracted to powers and existences other than the power of Allah. The most bitter experiences she had would make her understand the meaning of being and the meaning of the Creator. It is here, she can learn all kinds of lessons: life is really a game; the world is mortal, calamities are beauty; the afterlife is the goal; good looks and beauty are fake; the sparkling world is emptiness. More deeply, she can understand the nature of life and death; she could feel that Allah's punishments were terrible; awe of His greatness will flourish.[17, p. 100]

"He will be able to see essence after essence which other human beings cannot see. He will feel the secrets of creation and a million other secrets that make him acknowledge the truth of Allah SWT with everything that is in Him. So, it's no wonder humans who can learn lessons and knowledge at their lowest point, they will be able to see the might of Allah. His testimonies of the greatness of His might and the greatness of His power will have a profound impact on his life and send him flying like a meteor to the center of life. So, it is not surprising that we often hear their unique stories that are no longer rational." [17, pp. 100-101]

In another part, Masriyah Amva without hesitation affirms his belief that by choosing the path to God, then giving up everything that happens according to His will, and asking for all His goodness when we are hurt, then all this will be the right moment reach for self-strength. Because when we are wronged, our prayers are heard by God.[13, p. 58] Therefore, when we are hurt, insulted, and abused by others, we immediately complain to Allah. We only ask to be loved and loved by Him. In this way, we have succeeded in turning his poignant moans into melodious songs dedicated to God. She Wrote:

"I was moaning in pain, whining, screaming, crying uncontrollably before Allah. I complained about everything, something so trivial that made me sad and painful. All small problems, even those that are not a problem, I make a big problem before Him. I really feel satisfied and comfortable spoiled in my complaint. I don't care about my complaints and my prayers are granted or not. I just want to be comfortable and feel more at ease. I don't wait for all my hopes to come true because waiting is something very boring. Especially if the request is not granted.’[18, p. 23] 
According to Masriyah Amva, Allah does and acts according to His will, it is not humans will. He (God) will give when needed and will refuse when it does not benefit. He always educates with the hardships and hardships of life, not with comfort. He is very gentle when we approach Him very hard. He who regulates the time of education and who regulates when to finish. He controls what is best for us, not we who want what we want. He who governs us to be poor forever or become rich and then poor or poor once and then become rich. All in His knowledge and arrangement. He who chooses what is best for us, not us who chooses what is best in our opinion. So, in praying we must surrender everything in His arrangement.[18, pp. $23,26]$

After going through deep experiences and contemplation as we previously explained, Masriyah Amva boldly declared that approaching God is a necessity because there is a certain amount of peace. Starting from this, everyone who wants to rise from a downturn in his life should be obliged to approach God so that his soul is at ease. From this tranquility a person can have the energy to rise. In turn, a person will be able to think clearly. Thus, approaching God is a tool for someone to rise up, not just an arena where requests are made and granted by Him.[18, p. 26]

Masriyah Amva reminded about ordinary people who find it difficult to rise from a difficulty they face because they are approaching the wrong place. If they came to God, surely they would come with demand after demand. If these demands were not immediately fulfilled, they would soon leave His side and tire of living with Him. Then they will wildly look for other gods that they think will be able to solve the problem. As a result, they will be more entangled in very complicated problems.[18, p. 26]

\subsection{Seek God's Blessing: “Meeting” God}

In the process of seeking God's blessing, Masriyah Amva admitted that she had met God. This "encounter" with God, according to Amva's confession, was the result of a complicated, tortuous and very long process. Starting from this question: why did God make me so weak and have so many shortcomings? Why did I grow up with disgraceful habits? What is my life for and what does it mean I live for?; in addition, she also did deep contemplation and regret for everything that was happening in him, so he then began to learn to "come to" God in her daily life with prayers and small jobs to hope for His love.[13, p. 9]

In other writings, Amva said that the meeting of two figures, a weak servant with Almighty God, will be able to realize happiness and the awesomeness of life. The meeting between the Supreme Regulator and the naive servant will create a strong personality which is able to face the hardships of life that often throws and destroys and will foster serenity, bring out solutions to various life problems currently being faced, as well as create dreams and hopes.[19, p. 174] After "meeting" with God, Masriyah Amva was able to understand why God created him with a million weaknesses and shortcomings. In fact, all the weaknesses he had felt so far that he was insulted and ridiculed brought him to know His love and to know His power.[13, p. 9]

There is another reason that led Masriyah Amva to come to Allah, namely her failure in managing the female pesantren. She admitted that the pesantren she founded had indeed been visited by female santri, but they only lasted three or four days and chose to leave the pesantren. Although there have been various efforts and promotions to get female pesantren to get enthusiasts, they failed miserably. When Masriyah Amva was on the verge of despair and helplessness, suddenly crossed her mind a gap that she had never occurred to her at all. The gap is coming to Allah.She found the figure of Allah as God Almighty, Most Helping and 
Giving. She began to try to see a figure that she had known, but was very foreign to her.[13, $\mathrm{p}$. 150] She said:

"... since that time I started coming to Allah. Secretly, I began to kneel before Him, began to get acquainted with Him, began to ask for His love, began to complain about all pleas and sorrows...whoever pleads with Him, complains and leaves all matters to Him, surely Allah help him. This is a way to reach strength.'[13, p. 150]

What Masriyah Amva experienced and felt was a sign of turning someone away from something other than Allah, and only focusing on Allah. His heart had become righteous and knew God. This statement can be explained from a Sufi perspective, one of which is from Shaykh 'Abdul Qādir al-Jīlān̄i. According to Shaykh al-Jīlān̄̄, when a person has turned away from everything other than Allah. His heart is right and knows Allah, so he will deny everything other than Him, be friendly with Him, rest with Him, and feel tired with other than Him.[20, p. 234]

Shaykh al-Jīlānī emphasized that a person who claims to love Allah must realize that his love for Him will not be perfect until various directions are closed in on his rights. That is, nothing remains in him except in one direction. He is obliged to get the creature out of his heart; from inside the palace to the wet ground. In this way, one does not love the world, nor the hereafter. The world was disgusted by him and he felt tame and close to Allah. She was as mad as Laela-Majnun mad when love came over them both; he came out of the human environment and was willing to be alone and associate with wild animals. He came out of the crowd and was willing to be in destruction. It comes out of the creature's praise and insults. Their every word and their silence, for him became one. Willingness and hatred, for him to be one. One day Majnun was asked, "Who are you?" He replied, "Laela." When asked again, "Where did you come from?" He replied, "Laela." When asked again, "Where are you going?" He replied, "Laela." He is blind to other than Laela and he is deaf from hearing anything other than Laela's words. He never turned away from remembering his lover even because of the critic's insults.[20, p. 155]

From the perspective of Shaykh 'Abdul Qādir Jīlānī it can be described that Masriyah Amva's mental condition above is actually in a good heart condition, that is, when the heart is good, the limbs are good too. If the liver is clean, then the limbs are clean too. If he gets a gift, then he will be given the gift of heaven. If the liver is healthy, the body is healthy too. A healthy heart arises from a healthy inner relationship between humans and God. The mind is like a bird and the heart is like a cage. The body is like a bird and the grave becomes its cage. The grave becomes a cage for the heart. The grave is a certainty that they must enter.[20, p. 156]

\subsection{Giving Values and Meaning of Life}

The third reason that becomes the basis for Masriyah Amva's transformation is to give value and meaning to life. This reason, when viewed from the perspective of Martin E. P. Seligman, is a manifestation of Masriyah Amva who is in a good life and has found authentic happiness that comes from harnessing the unique powers of each day in the main areas of life. A meaningful life adds one more component: harnessing the same power to preserve knowledge, mastery, or goodness. Living like that is a life of meaning.[21, p. 332] With regard to authentic happiness, Amva has found that happiness that encourages him to give value and meaning to life. He emphasized that happiness comes from happy feelings that can be created by everyone through deep feelings of gratitude. He always tries to learn to accept whatever happens as happiness. Negative thoughts, the demands of life that are considered necessities 
are never given a place to feel the happiness and perfection of his life. Added by Amva, if a person feels that his life is imperfect, less happy, loses his needs, then he will only experience the torment of life. Therefore, the most important thing is to maintain gratitude which will have an impact on the peace of the soul.[14, pp. 194-195]

The question that arises within the boundaries of humanity is how to make happiness truly felt until the end of life? In fact, the main key to happiness, according to Masriyah Amva, is 'we ourselves create.' $\left[14\right.$, p. 196] ${ }^{[38]}$ She emphasized that people are very capable of living without the love of their husbands if we are able to present another sense of love, namely God's love and care for us. A single person who previously used to live with a partner should be able to present a sense of the existence of God who always accompanies us with all love, affectionate attention that exceeds previous love and love. The existence of feelings like that will make us happier, more secure, more fulfilled and feel more alive with all its beauty. Thus, everyone is able to create a sense of God's presence if she wants to learn and is willing to surrender and be grateful.[14,pp. 196-197]

As for the token of gratitude she had received, Masriyah Amva wanted to devote her life to serving others. In other words, Amva does not want to be "a parasite that interferes with other people's lives" and "wants to live a useful life and bring prosperity to people, not bankruptcy."[13, pp. 104-405] During her journey, Masriyah Amva said that she was given the ability by God to support his family. Being able to be their backbone. Being able to help the lives of those who depend on it. Able to help difficult people and give prosperity to many people.[13, p. 106] By this principle, a person will get the blessing of life from God. God will always follow those who sincerely love and give to the weak. Whoever loves because of Allah, then He will reward him with happiness in this world and in the hereafter. High status, honor and prosperity will always follow those who struggle and care for the little people who live in suffering. See all religious advice always leads to the defense of weak people.[17, p. 85]

On the other hand, her love for the Beloved is transformed into strength, greatness, and light so that she does not want to be a weak and fragile woman. This can be listened to from the poetry she wrote on October 2, 2014.

No no ...

I don't want to be weak and fragile

I'm not an ordinary girl

I am an extraordinary woman born of strength

And created to always be strong and great

I was born to live, not to die

I was sent to be light

Who can light up every darkness.[6, p. 37]

The last two stanzas, "I was sent to be a light, capable of lighting every darkness" confirm the mission of change brought by Masriyah Amva, especially for women. The transformation carried out by Masriyah Amva is a form of Sufism in action. In the sufism in action, according to H. J. Witteveen emphasized that he wanted to refute the notion that has stuck in the minds of many people who identify Sufism as only dealing with mystical and spiritual experiences with God which is clearly not worldly. In the past, many Sufi orders that emphasized the inner life and search for God sometimes neglected the world. In the current context, the world must be used as part of the practice of Sufism, and not avoid it.[22] Thus, true Sufis are those who always try to serve society throughout their life. They seem to have no other choice but to 
work. In other words, these Sufis are always preoccupied with fellow members of society, while their hearts are filled with God. They are always intimate with God in the hands of society. In this case Sa'dī said, "Have you ever heard of a person who is and is not at the same time? I am in the hands of society, but my heart is in another place."[23, p. 19]

According to the Sufis, the harmony of life is a symbol of human perfection, and they believe that basically someone who is unable to live well with other humans is a sick person. Therefore, they also consider that those who withdraw from society and retreat to enhance their spiritual life are languishing and imperfect individuals. According to Osman Nuri Topbas, Allah has indeed created man to be the best of His creatures compared to His other creations. However, Allah also exaggerates one human being with another, such as there are rich, some are poor, some are strong, some are weak, some are healthy, some are sick, some are educated and some are illiterate. Seeing this fact, we are obliged to benefit everyone in different ways. He quoted Rūmī's words advising the importance of paying attention to the destiny of the poor: The poor man is a man full of knowledge, he has a house full of smoke (poverty and poverty): open the window to hear (his problems) (Masinawī, III: 485).[24, p. 187]

It should be underlined that in order to achieve perfection, one must be able to adapt and live in harmony with society. He served the community and did not offend others in the association. Contact with society is a test of his progress towards perfection, because only by living with society can he demonstrate his freedom from lust and that he has abandoned his ego. At this stage a Sufi is not bothered by the persuasions that others whisper to him. A follower who is still tempted and disturbed is judged as disbelieving (infidel).[23, p. 19]

\section{Conclusion}

Based on the description above, it can be concluded that the divine love that Masriyah Amva made the basis for transformation proves that a woman scholar is capable of contributing to others and humanity. By relying completely on God with a foundation of love and sincerity, the servant is a manifestation of a deep love for Him. This is the truth of the principle of 'serving to receive grace'; serving is a special step on the ladder that takes the heart to the sublime peak.

\section{References}

[1] O. Safi, Ed., Radical Love: Teaching From The Islamic Mystical Tradition. New Haven and London: Yale University Press, 2018.

[2] A. Q. Isa, Haquà'iq 'an al-Tașawwuf. Shuriah: Dār al-'Irfān, 2007.

[3] W. C. Chittick, The Sufi Path of Love: The Spiritual Teachings of Rumi. Albany: State University of New York Press, 1983.

[4] M. N. Kamba, Mencintai Allah Secara Merdeka. Tangerang: IIMan, 2020.

[5] M. Amva, Ketika Aku Gila Cinta. Cirebon: Noktah Tsaqofah, 2007.

[6] M. Amva, Tafakur Cinta. Cirebon: Kebon Jambu, 2015.

[7] A. Schimmel, My Soul is a Woman: The Feminine in Islam. New York: The Continuum Publishing Company, 1997.

[8] S. Sahal, "Introduction," in Ketika Aku Gila Cinta (Masriyah Amva), Cirebon: Noktah Tsaqofah, 2007, p. v. 
[9] A. Maslow, The Farther Reaches of Human Nature. Arkana: Penguin Books, 1971.

[10] B. J. Biddle and E. J. Thomas, Role Theory: Concept and Research. New York: Jhon Wiley \& Sons, Inc, 1966.

[11] M. Marhumah, "Gender dalam Lingkungan Sosial Pesantren: Studi tentang Peran Kiai dan Nyai dalam Sosialisasi Gender di Pesantren Al-Munawwir dan Pesantren Ali Maksum Krapyak Yogyakarta,” Pascasarjana UIN Suna Kalijaga Yogyakarta, 2008.

[12] R. M. Kartanegara, Renungan Mistik Jalal ad-Din Rumi. Jakarta: Pustaka Jaya, 1986.

[13] M. Amva, Cara Mudah Menggapai Impian. Bandung: Nuansa, 2008.

[14] M. Amva, Menggapai Impian: Pengalaman Spiritual Seorang Hamba yang Menyerahkan Diri secara Total Kepada Tuhan. Jakarta: Kompas Gramedia Group, 2010.

[15] M. Amva, Meraih Hidup Luar Biasa Melalui Kekuatan Doa dan Iman. Jakarta: Kompas Gramedia Group, 2010.

[16] K. H. H. Muhammad, "Selamanya Jadilah Pecinta," in Rahasia Sang Maha: Mengubah Derita Jadi Bahagia (Masriyah Amva), Jakarta: Kompas, 2012, pp. xvi-xvii.

[17] M. Amva, Rahasia Sang Maha: Mengubah Derita Jadi Bahagia. Jakarta: Kompas Gramedia Group, 2012.

[18] M. Amva, Bangkit dari Terpuruk: Kisah Sejati Seorang Perempuan tentang Keagungan Tuhan. Jakarta: Kompas Gramedia Group, 2010.

[19] M. Amva, Umrah Perjalanan Spiritual. Jakarta: Elex Media Komputindo - Kompas Gramedia Group, 2013.

[20] S. 'Abdul Q. J̄̄lān̄̄, al-Fath al-Rabbān̄̄ wa al-Faid al-Rahmānī. Beirut: Dār al-Kutub al-'Ilmiyah, 1988.

[21] M. E. P. Seligman, Authentic Happiness: Using the New Positive Psychology to Realiz Your Potential for Lasting Fullfilment. New York: The Free Press, 2002.

[22] H. J. Witteveen, "Sufism in Action: Achievement, Inspiration and Integrity in a Tough World." Vega Books, London, 2002.

[23] Z. Kamal, "Tasawuf dan Tarekat: Ajaran Esoterisme Islam," in Manusia Modern Mendamba Allah: Renungan Tasawuf Positif, A. N. Burhani, Ed. Jakarta: IIMan and Hikmah, 2002, p. 19.

[24] O. N. Topbaş, Islam: Spirit and Form. Istanbul: Erkam Publications, 2012. 
